\title{
Timotein kukintaan virittyminen ja sen yhteys korren laatuominaisuuksiin
}

\author{
Mervi M. Seppänen ${ }^{1)}$, Kirsi Pakarinen ${ }^{2}$, Venla Jokela $^{1)}$, Arja Santanen ${ }^{1)}$ ja Perttu Virkajärvi ${ }^{2)}$ \\ ${ }^{1)}$ Maataloustieteiden laitos, Latokartanonkaari 5-7, 00014 Helsingin yliopisto, \\ etunimi.sukunimi@helsinki.fi \\ ${ }^{27}$ MTT Kotieläintuotannon tutkimus, Halolantie 31 A, 41450 Maaninka, etunimi.sukunimi@mtt.fi
}

\section{Tiivistelmä}

Kasvuston rakenne määrää suurelta osin nurmikasvien sadon määrän. Tämä havaitaan selvimmin vertailtaessa timotein kevät- ja syyskasvustojen rakennetta ja sadon määrää; kevätsadossa esiintyy runsaasti korrellisia, kukintoja muodostavia versoja, kun taas syksyllä kasvusto on matalaa ja lehtevää, ja kortta muodostavien versojen määrä on alhainen. Kevätsato on myös määrällisesti suurempi. Korrellisten ja kukintoja muodostavien versojen määrä ohjailee myös nurmisadon laadun kehittymistä, sillä korren puutuminen kehityksen edetessä alentaa nopeasti rehun sulavuutta. Koska korren kasvulla ja kukkimisella on suuri merkitys nurmisadon määrään ja laatuun, on kukinnan säätely myös yksi merkittävä jalostuskohde nurmilla. Tässä tutkimuksessa selvitettiin korrenkasvun ja kukinnan virittymisen säätelyä sekä kärkikasvupisteen kehitysasteen ja korren lignifikoitumisen yhteyttä Viikin kasvihuoneissa ja MTT Maaningan tutkimusaseman pellolla järjestetyissä kokeissa. Kukintaan virittävistä säätelytekijöistä tutkittiin kasvihuoneella eripituisten vernalisaatioaikojen vaikutusta kukkivien versojen määrään, kahden vernalisaatiota ohjailevan geenin kukinnan indusoijan VRN1 ja kukinnan estäjän VRN2 ilmenemiseen sekä versojen kylmänkestävyyteen. Peltokokeesta kerätyistä näytteistä selvitettiin kärkikasvupisteen kehitysasteen yhteyttä korren morfologiaan ja lignifioitumiseen sekä vernalisaatiogeenien ilmenemiseen kevät- ja syyssadoissa. Timotei on pitkän päivän kasvi eikä tarvitse välttämättä vernalisaatiota kukkiakseen. Kontrolloiduissa vernalisaatio- ja päivänpituusoloissa tehdyt kokeet kuitenkin osoittavat, että vernalisaatio nopeuttaa ja synkronoi versojen kehitystä sekä lisää kukkivien versojen lukumäärää kasvustossa. Vernalisaatiopituudessa havaittiin optimi, jonka jälkeen korrellisten ja kukkivien versojen määrä väheni. Timoteigenotyyppien välillä havaittiin eroja niiden vernalisaatiovasteessa sekä eivernalisoituneiden versojen kyvyssä tuottaa korrellisia versoja. Kärkikasvupisteen kehitysasteella tai siirtymisellä kasvullisesta suvulliseen vaiheeseen, ei havaittu olevan vaikutusta kortta tukevan ja korren sulavuutta tehokkaasti alentavan puutuneen tukisolukkovaipan muodostumiseen. Kevätsadon korsien puutuminen alkoi aikaisemmissa kärkikasvupisteen kehitysasteissa kuin syyssadossa. Kevätsadossa kärkikasvupisteen siirtyminen kasvullisesta generatiiviseen oli yhteydessä korkeaan VRN1 geenin ilmenemisen kanssa, mutta syyssadossa VRN1 ilmenemistä ei havaittu. Tutkimuksen tulokset osoittavat, että timoteillä kärkikasvupisteen kehitysaste ei ole yhteydessä korren pituuteen tai puutuneen tukisolukon muodostumiseen. Vernalisaatio nopeuttaa kehitystä ja korteen kehittyy hyvin varhaisessa vaiheessa puutunut tukisolukko ja korsi onttoutuu. Korren morfologiassa ja korkeudessa havaitut erot mahdollisesti selittävät kevät- ja syyssadon korsien erilaisen sulavuuden. Kukintaa edistävän vernalisaatiogeeni VRN1 ilmeneminen oli yhteydessä kärkikasvupisteen kehitysasteeseen, mutta $V R N 2$ geenin ilmenemisestä saadut tulokset viittaavat siihen, että timotein kukinnan virittyminen on säädelty erilailla kuin syysviljoilla. Tässä tutkimuksessa saadut tulokset antavat ensimmäisiä viitteitä niistä säätelytekijöistä, jotka vaikuttavat timotein sadon määrään ja laatuun Suomessa.

\section{Avainsanat}

Korren kasvu, kukinta, kylmänkestävyys, lignifikaatio, timotei, vernalisaatio, VRN1, VRN2 


\section{Johdanto}

Nurmikasvuston rakenne ja erityisesti korrellisten versojen määrä vaikuttaa merkittävästi kuivaainesadon määrään. Korren kasvu ja kärkikasvupisteen siirtyminen lehtiä muodostavasta kasvullisesta (vegetatiivinen) kukintorakenteita muodostavaan suvulliseen vaiheeseen (generatiivinen) tapahtuvat monilla kasvilajeilla ajallisesti hyvin lähekkäin, jopa niin, että niiden on päätelty olevan sidoksissa toisiinsa. Kukinnan virittymistä ja usein myös korrenkasvun alkua säätelevät ympäristöstä peräisin olevat signaalit kuten vernalisaatio ja päivänpituus sekä kasvin sisäiset tekijät kuten gibberelliinihappo ja kasvin ikä ja koko (Greenup ym. 2009). Nurmikasvit voidaan vernalisaatiovaatimuksensa perusteella jakaa eri ryhmiin, nk. kaksoisinduktion vaativiin lajeihin kuten Festuca-suvun heinät ja Lolium perenne, jotka vaativat kylmäkokemisen jälkeen riittävän pitkän päivänpituuden kukintorakenteiden kehittymistä varten (Heide 1994). Toisaalta timotei luokitellaan pitkän päivän kasviksi, joka muodostaa kukintorakenteita kriittisen päivänpituuden ylittyessä. Korsifraktion osuuden lisääntyminen nurmirehussa on yhteydessä rehun sulavuuden nopeaan alenemiseen (Akin 1989). Korren puutumisen eli lignifikoitumisen edetessä korteen muodostuu lignifioitunut tukisolukkovaippa, joka estää tehokkaasti mikrobisulatusta (Grabber ym 1992, Wilson ja Hatfield 1997). Edellä mainitut tekijät yhdessä johtavat yleisesti tunnettuun nurmirehun sadon määrän ja laadun negatiiviseen korrelaatioon. Timotein kevät- ja syyssadosta tehdyt tarkemmat analyysit kuitenkin osoittavat, että syyssadossa esiintyvät kukintoja muodostamattomat korret eli nk. elongoituvat korret, voivat olla sulavuudeltaan kevätsadon korsia parempia (Pakarinen ym. 2008). Tässä tutkimuksessa selvitettiin syitä kevät- ja syyssadon korsien erilaiselle sulavuudelle sekä tutkittiin kasvustorakennetta säätelevistä tekijöistä vernalisaation vaikutusta timotein satoa muodostavien versojen määrään.

\section{Aineisto ja menetelmät}

Peltokokeet (cv. Tammisto II) järjestettiin MTT Maaningan tutkimusasemalla ja koeruuduista kerättiin näytteitä aikasarjana anatomisia analyysejä ja RNA:n eristämistä varten sekä kevät- että syyssadosta. Näytteenoton yhteydessä kärkikasvupisteen kehitysaste määritettiin Sweet ym. (1991) kehittämän asteikon mukaan ja samalla mitattiin myös verson korkeus. Anatomisia analyysejä varten kerättiin korsinäytteitä formaliini-etikkahappoliuokseen (FAA) ja näytteistä leikattiin 8-12 $\mu \mathrm{m}$ paksuisia leikkeitä, jotka värjättiin safraniinillä. Kasvihuoneella tutkittavia timoteigenotyyppejä (cv. Iki) kasvatettiin kaksi viikkoa $\left(20^{\circ} \mathrm{C}, 12\right.$ tunnin päivänpituus) ennen siirtämistä kasvatuskaappeihin (Weiss Technik, Saksa) 0, 2, 10, 18, 20 viikon vernalisaatiokäsittelyyn $\left(6^{\circ} \mathrm{C} / 4^{\circ} \mathrm{C}\right.$, päivä/yö, 8 tunnin päivänpituus). Vernalisaatiokäsittelyn jälkeen kärkikasvupisteen kehitysaste määritettiin Sweet ym. (1991) kehittämän asteikon mukaan ja kasvit siirrettiin kasvihuoneelle 16 tunnin päivänpituuteen. RNA näytteitä kerättiin lehdistä ja kärkikasvupisteestä 7-28 vrk vernalisaation jälkeen ja kukkivien versojen määrän kehittymistä seurattiin 5-6 viikon ajan kunnes uusien versojen muodostuminen oli loppunut. Kylmänkestävyys mitattiin jälleenkasvutestillä heti vernalisaatiokäsittelyiden päätyttyä. Vernalisaatiogeenien eristämistä varten tuotettiin alukkeet tunnetuille Lolium perenne, L. temulentum ja Triticum aestivum VRN1 ja VRN2 geeneille, ja saatujen sekvenssitietojen perusteella suunniteltiin timotein lajispesifiset alukkeet kvantitatiivistä PCR analyysiä (ABI7000, Foster City, USA) varten (Seppänen ym. 2009). Timoteigenotyyppien välisiä eroja niiden vernalisaatiovasteessa tutkittiin edellä kuvatuissa oloissa kahden viikon vernalisaatiokäsittelyn jälkeen (cv. Iki, Tuure, Tammisto II, Tika, Tia, BOR01025, Grindstat ja Jonathan).

\section{Tulokset ja tulosten tarkastelu}

\section{Korren ligniinivaipan muodostuminen}


Korren sulavuuden alenemisen on havaittu olevan yhteydessä kukkivien korsien runsaan lignifikaation kanssa (Akin 1989, Grabber ym. 2005) ja siksi yksi merkittävä nurmikasvien jalostuksenkohde onkin ollut kukinnan säätely, jota muokkaamalla pyritään vaikuttamaan myös nurmirehun laatuominaisuuksiin (Jensen ym. 2004). Tässä tutkimuksessa selvitettiin miten kärkikasvupisteen kehitysaste tai sadonkorjuukerta vaikuttaa korressa esiintyvän ligniinivaipan muodostumiseen. Erityisesti haluttiin selvittää miksi syyssadon korsifraktion oli havaittu olevan sulavuudeltaan parempaa kuin kevätsadon vastaavan (Pakarinen ym. 2008). Peltokokeissa kerätyistä leikenäytteistä tutkittiin ligniinivaipan muodostumista eri-ikäisissä timotein aitokorrellisissa versoissa. Tulosten perusteella voidaan todeta, ettei lignifioituneen tukirenkaan muodostuminen ollut yhteydessä kärkikasvupisteen kehitysasteeseen tai siirtymiseen kasvullisesta vaiheesta suvulliseen vaiheeseen (Kuva 1).

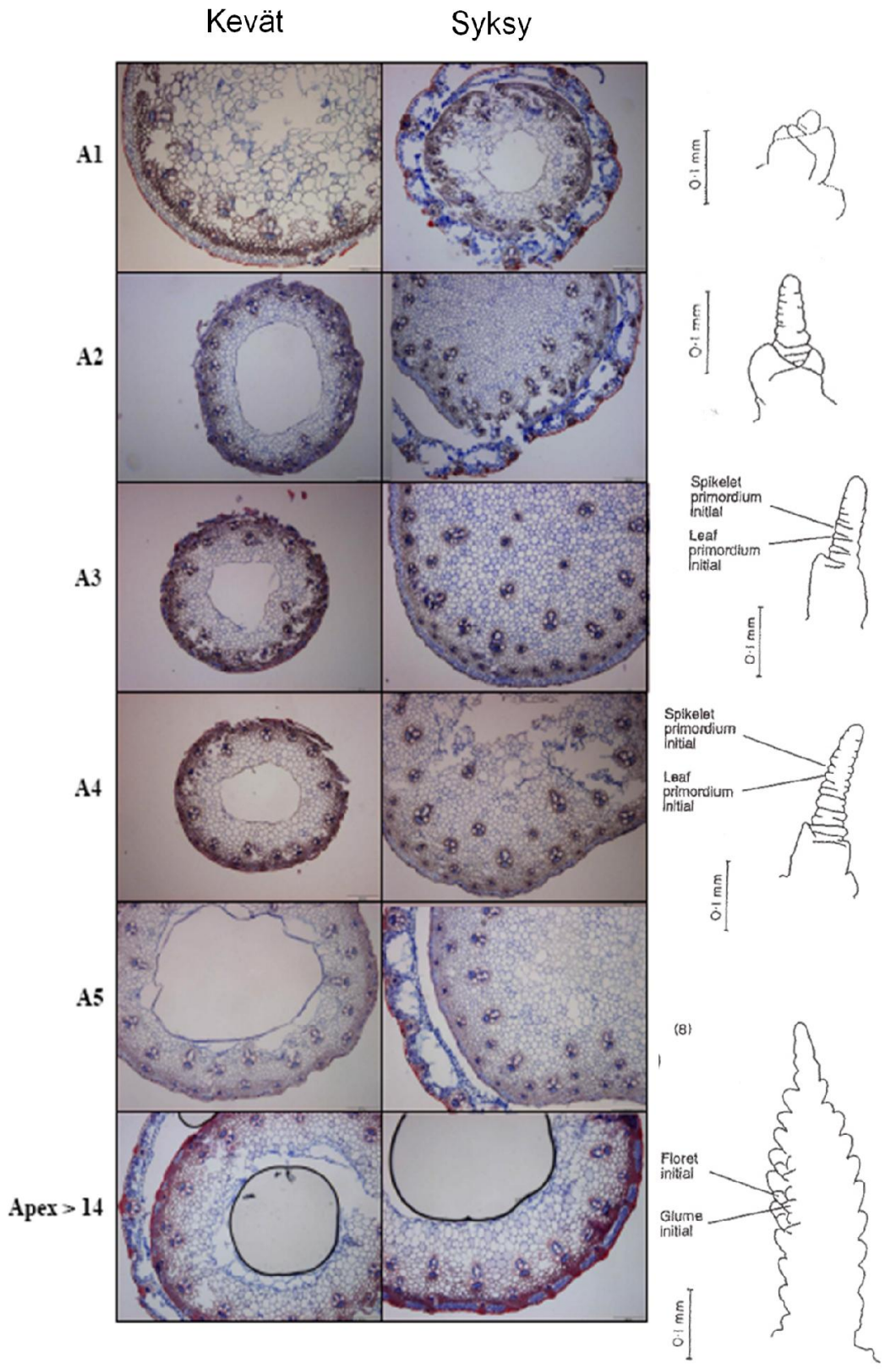

Kuva 1. Korren keskimmäisen solmuvälin lignifikoituminen kevät- ja syyssadossa ja kärkikasvupisteen kehitysaste (Sweet ym. 1991 mukaan). Kärkikasvupiste siirtyy kasvullisesta suvulliseen vaiheeseen siirtyessään vaiheesta A3 vaiheeseen A4. Näytteet kerättiin aikasarjana kevätsadossa 11.-18.6. ja syyssadossas 16.7-13.8. välisenä aikana. 
Lignifioitunut tukisolukko havaittiin kevätsadon versoissa jo kärkikasvupisteen ollessa kasvullisessa kehitysasteessa (A1-A3). Myös syyssadossa korren lignifioituminen alkoi huomattavan varhain, eikä ollut yhteydessä kärkikasvupisteen kehitykseen, kuten aiemmin on yleisesti oletettu. Syyssadon korret olivat kuitenkin morfologialtaan erilaisia eivätkä ne onttoutuneet yhtä nopeasti kuin kevätsadon korret. Kaiken kaikkiaan korsien lignifikoituminen oli yhteydessä korren korkeuteen ja siten korren tukisolukon tarve oli yhteydessä kasvuston korkeuteen (Taulukko 1). Kärkikasvupisteen kehitysasteella ei ollut yhteyttä kasvuston korkeuteen, mutta syyssadon korret olivat keskimäärin matalampia kuin kevätsadon korret. Kevät- ja syyssadon korren morfologiassa ja korkeudessa havaitut erot voivat osittain selittää sitä, miksi syyssadon korsifraktion sulavuus säilyy kevätsadon korsia parempana.

Taulukko 1. Timotein kärkikasvupisteen kehitysvaiheen (A1 - A14) ja keskimääräisen solmuvälin pituuden $(\mathrm{mm})$, korren kokonaiskorkeuden $(\mathrm{mm})$, ylimmän kielekkeen ja kärkikasvupisteen korkeuden $(\mathrm{mm})$ välinen yhteys kevät- ja syyssadossa. Näytteiden keräysajankohdat on esitetty Kuvassa 1.

\begin{tabular}{lcccccccc}
\hline & \multicolumn{2}{c}{$\begin{array}{c}\text { Solmuvälin } \\
\text { pituus }\end{array}$} & \multicolumn{2}{c}{$\begin{array}{c}\text { Kokonais- } \\
\text { korkeus }\end{array}$} & \multicolumn{2}{c}{$\begin{array}{c}\text { Kielekkeen } \\
\text { korkeus }\end{array}$} & \multicolumn{2}{c}{ Kärkikasvu- } \\
& pisteen korkeus \\
& Kevät & Syys & Kevät & Syys & Kevät & Syys & Kevät & Syys \\
\hline A1 & 101 & 22 & 652 & 237 & 479 & 104 & 426 & 48 \\
A2 & 106 & 53 & 573 & 528 & 381 & 222 & 367 & 165 \\
A3 & 90 & 65 & 570 & 584 & 402 & 337 & 347 & 270 \\
A4 & 92 & 25 & 562 & 545 & 375 & 328 & 320 & 95 \\
A5 & 69 & - & 416 & - & 190 & - & 95 & - \\
A10 & 68 & 73 & 454 & 572 & 226 & 319 & 122 & 223 \\
A12 & 28 & 68 & 756 & 493 & 437 & 296 & 93 & 209 \\
A14 & 120 & - & 710 & - & 513 & - & 477 & - \\
\hline yhteensä kpl & 111 & 62 & 111 & 62 & 111 & 62 & 109 & 62 \\
$\boldsymbol{p}$-arvo & - & - & $<0.0001$ & 0.015 & $<0.0001$ & 0.030 & $<0.0001$ & 0.026 \\
merkitsevyys & & & $* * *$ & $*$ & $* * *$ & $*$ & $* * *$ & $*$ \\
\hline
\end{tabular}

\section{Vernalisaation vaikutus kasvuston rakenteeseen}

Timotei on pitkän päivän nurmikasvi, joka ei välttämättä tarvitse vernalisaatiokäsittelyä kukkiakseen (Heide 1994). Tässä tutkimuksessa riittävän pitkä vernalisaatio kuitenkin nopeutti merkittävästi kukkivien versojen muodostumista sekä lisäsi niiden määrää. Verrattaessa eri timoteigenotyyppejä havaittiin niiden vernalisaatiovasteessa olevan jonkin verran eroja erityisesti eteläisten ja pohjoisten genotyyppien välillä. Eteläisten genotyyppien vernalisaatiovaatimus oli kokeissa vähäisempi kuin pohjoisten, mikä havaittiin nopeana kortta muodostavien ja kukkivien versojen muodostumisena myös ei-vernalisoituneissa kasveissa. Tämä havainto saattaa selittää joidenkin lajikkeiden satoisuutta toisessa niitossa, joka koostuu kesällä kasvaneista vernalisoitumattomista versoista. Syysviljoilla vernalisaatiovaatimuksen täyttyminen ja siirtyminen kasvullisesta suvulliseen vaiheeseen on yhteydessä kylmänkestävyyden alenemiseen sekä kukinnan indusoijan VRN1-geenin ilmenemisen lisääntymiseen (Danyluk ym. 2003). Kasvatuskaappikokeissa suvullisia kärkikasvupisteitä havaittiin ensimmäisen kerran 10 viikon vernalisaation jälkeen. Testattaessa timotein kylmänkestävyyttä eripituisten vernalisaatioaikojen jälkeen todettiin, ettei siirtyminen suvulliseen vaiheeseen tai korkea VRNl-geenin ilmeneminen johtanut alentuneeseen kylmänkestävyyteen. Itse asiassa kukkivia kortta muodostavia versoja muodostui pitkän vernalisaatiokäsittelyn jälkeen vielä ${ }^{-} 15^{\circ} \mathrm{C}$ kylmäkäsittelyn jälkeen. Samaan aikaan testattujen ruokonatojen kestävyys sen sijaan oli vain ${ }^{-} 5^{\circ} \mathrm{C}$. 


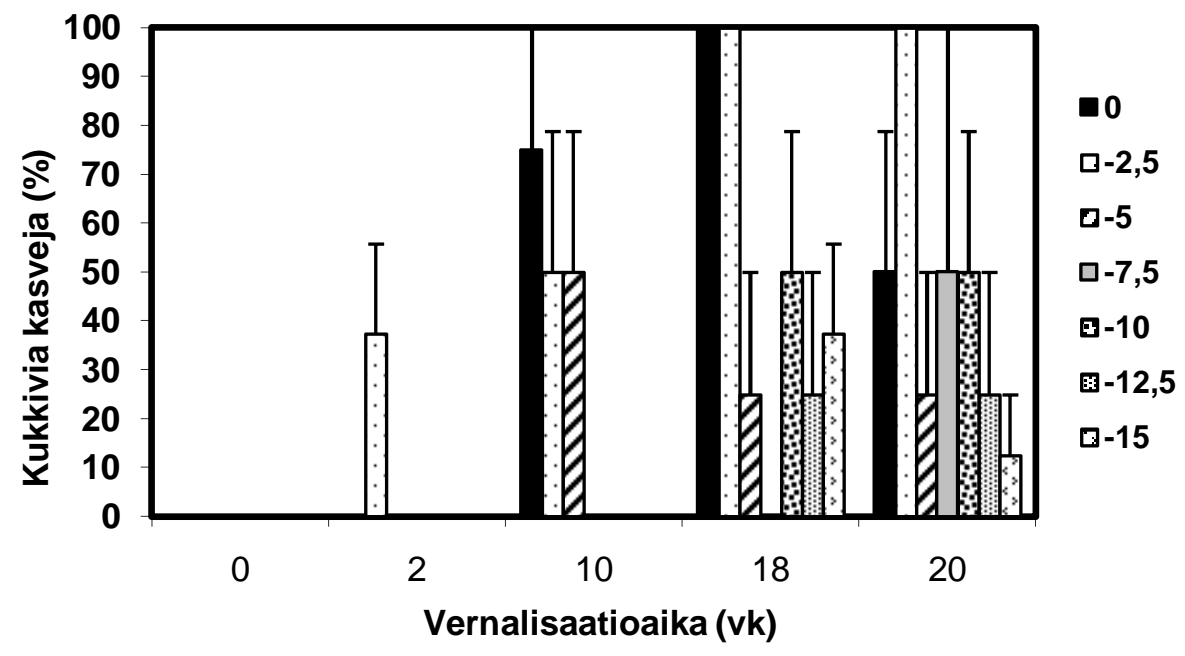

Kuva 2. Eripituisia aikoja (0-20 viikkoa) vernalisoituneiden timoteiversojen kylmänkestävyys mitattuna kukkivien versojen määränä (\% kaikista versoista) kylmäkäsittelyn jälkeen ${ }^{-} 2.5^{\circ} \mathrm{C}$ ${ }^{-} 15.0^{\circ} \mathrm{C}$.

Tutkimuksen toisessa osassa selvitettiin VRN1- ja VRN2-geenien ilmenemistä kortta muodostavissa timotein versoissa kevät- ja syyssadossa. VRN1 ilmeneminen, joka indusoi kukkimista, ajoittui kevätsadossa ajankohtaan, jolloin kärkikasvupiste oli siirtymässä kukintorakenteita muodostavaan vaiheeseen (Kuva 3). Myös VRN2-aktiivisuus, joka estää kukintaa, oli korkein juuri ennen kukintorakenteiden muodostumista. Sen sijaan VRN2, jonka tiedetään syysviljoilla estävän kukkimisen alkamista talvea vasten (Trevaskis ym. 2007), ei aktivoitunut syyssadon korrellisissa versoissa. Tulosten perusteella voidaan todeta, että VRN1geeni ohjailee kukkimisen alkamista timoteillä keväällä samantapaisesti kuin syysviljoilla, mutta kukkimisen estäjä toiminee nurmilla erilailla kuin viljoilla.

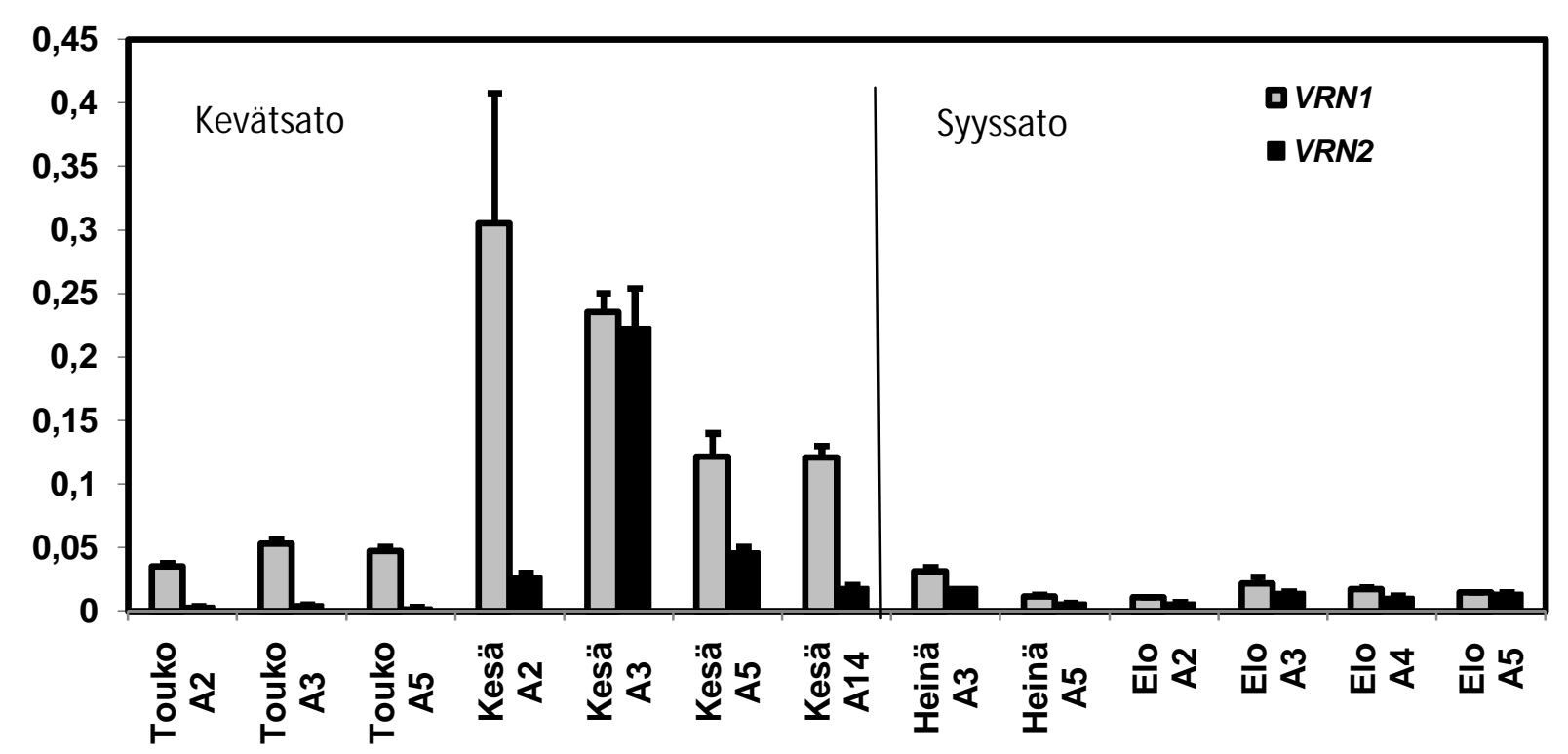

Kuva 3. Kahden vernalisaatiogeenin, $V R N 1$ ja $V R N 2$, suhteellinen ilmeneminen kortta muodostavissa versoissa kärkikasvupisteen eri kehitysasteissa (A2-A14) kevät- ja syyssadossa. 


\section{Johtopäätökset}

Timotein kevät- ja syyssadon korsien morfologiassa havaittiin eroavaisuuksia, kuten kevätsadon korsien onttoutuminen varhaisemmassa kärkikasvupisteen kehitysasteessa, mikä voi selittää osittain aiemmin havaittuja eroja kevät- ja syyssadon korsien sulavuuksissa. Korteen kehittyi keväällä myös hyvin nopeasti lignifikoitunut tukisolukkovaippa, joka alentaa korren sulavuutta. Lignifioituneen tukisolukkovaipan muodostuminen ei ollut yhteydessä kärkikasvupisteen kehitysasteeseen, eikä kärkikasvupisteen siirtyminen suvulliseen vaiheeseen ole edellytys korren lignifikoitumiselle kuten aiemmin on oletettu. Sen sijaan lignifikoituminen oli yhteydessä korren pituuteen. Kortta kasvavien versojen kärkikasvupisteen siirtyminen suvulliseen kehitysvaiheeseen tapahtui samanaikaisesti kukkimista indusoivan VRN1 geenin ilmenemisen kanssa. Syyssadon korsissa VRN1 tai kukkimista estävän VRN2 transkriptejä ei kertynyt, mikä viittaa siihen, että syyssadon korsien kehitystä ohjailevat eri geenit kuin kevätsadossa.

\section{Kirjallisuus}

Akin, D.E. 1989. Histological and physical factors affecting digestibility of forages. Agronomy Journal 81: 17-25.

Danyluk, J., Kane, N.A., Breton, G., Limin, A.E., Fowler, B. \& Sarhan, F. 2003. TaVRT1, a putitative transcription factor associated with vegetative to reproductive transition in cereals. Plant Physiology 132: 1849-1860.

Grabber, J.H., Jung, G.A., Abrams, S. \& Howard D.B. 1992. Digestion kinetics of parenchyma and sclerenchyma cell walls isolated from orchardgrass and switchgrass. Crop Science 32: 806-810.

Greenup, A., Peacock, W.J., Dennis, E.S. \& Trevaskis, B. 2009. The molecular biology of seasonal flowering-responses in Arabidopsis and the cereals. Annals of Botany 103: 1165-1172.

Heide, O.M. 1994. Control of flowering and reproduction in temperate grasses. New Phytologist 128: 347-362.

Jensen, C.S., Salchert, K., Gao, C., Andersen, C.H., Didion, T \& Nielsen, K.K. 2004. Floral inhibition of red fescue (Festuca rubra L.) through expression of a heterologous flowering repressor from Lolium. Molecular Breeding 13: 37-48.

Pakarinen, K., Virkajärvi, P., Seppänen, M. \& Rinne, M. 2008. Effect of different tiller types on the accumulation and digestibility of the herbage mass of timothy (Phleum pratense L.). Grassland Science in Europe 13: 495-497.

Seppänen, M.M., Pakarinen, K., Jokela, V., Andersen, J.R., Fiil, A., Santanen, A. \& Virkajärvi, P. 2009. Vernalization response in Phleum pratense and relationship to canopy structure, stem morphology and experession of VRN1 and VRN2. Annals of Botany, käsikirjoituksen korjausvaiheessa.

Sweet, N., Wiltshire, J.J.J. \& Baker, C.K. 1991. A new descriptive scale for early reproductive development in Lolium perenne L. Grass Forage Science 46: 201-206.

Trevaskis, B., Hemming, M.N., Dennis, E.S. \& Peacock, W.J. 2007. The molecular basis of vernalization-induced flowering in cereals. Trends in Plant Science 12:352-357.

Wilson, J.R \& Hatfield, R.D. 1997. Structural and chemical changes in cell wall types during stem development: consequences for fibre degradation by rumen microflora. Australian Journal of Agricultural Research 48: 165-180. 